\title{
IMPLEMENTASI METODE PROBLEM-BASED LEARNING (PBL) UNTUK OPTIMALISASI STUDENT-CENTERED LEARNING (SCL) DI PERGURUAN TINGGI
}

\author{
Putu Santi Oktarina \\ Institut Hindu Dharma Negeri Denpasar \\ putusantioktarina@gmail.com
}

Diterima 05 Januari 2017, direvisi 30 Januari 2017, diterbitkan 28 Pebruari 2017

\begin{abstract}
Students at higher education institutions are definitely adults who should be encouraged and given motivation to be the 'adult' learners. Each student has diverse characteristics that will make them ultimately bring different perspectives to the class (different types of backgrounds, learning styles, experiences, and aspirations). Therefore, educators are no longer possible to use conventional methods in cultivating the values to students to get them to be adult learners. The psychological condition of adults will encourage the teaching and learning process to be more directed to the Student-Centered Learning. This method is built on the principles of active learning constructive, some social activity, mental reflection, implementation of prior knowledge, and so forth. The learning process is a reflection cycle (about what happened), the idea of a thing (or something that needs to be tested), action (trial to do something), and outcomes (concrete experience). Problem-Based Learning method is an option that can be used to support the activities of StudentCentered Learning for the use of problems in the learning process can trigger the curiosity of students that will lead them to be able to solve their own problems by giving a definition of a certain problem and specify the collected information. In this way, students will try to associate the information they have and be able to specify the topics they will learn more.
\end{abstract}

Keywords: Methods of Problem-Based Learning (PBL) and Student-Centered Learning (SCL)

\begin{abstract}
ABSTRAK
Mahasiswa pada lembaga pendidikan tinggi adalah orang-orang dewasa yang mesti didorong dan diberikan motivasi untuk menjadi pelajar yang 'dewasa'. Tiap mahasiswa memiliki karakteristik beragam yang pada akhirnya mereka membawa berbagai perspektif ke dalam kelas (berbagai jenis latar belakang, gaya belajar,
\end{abstract}


pengalaman, serta aspirasi). Oleh karenanya, pendidik tidak dimungkinkan lagi menggunakan metode konvensional untuk penanaman nilai-nilai terhadap mahasiswa dalam rangka menjadikannya pembelajar dewasa. Kondisi psikologis orang dewasa mendorong proses belajar mengajar lebih ke arah pembelajaran yang berpusat pada siswa (Student-Centered Learning). Metode ini dibangun atas prinsip-prinsip pembelajaran aktif-konstruktif, juga beberapa aktivitas sosial, refleksi mental, implementasi prior knowledge, dan lain sebagainya. Proses pembelajaran adalah sebuah siklus refleksi (tentang apa yang telah terjadi), ide untuk suatu hal (atau sesuatu yang perlu dicoba), tindakan (percobaan melakukan suatu hal), dan hasil (pengalaman konkrit). Metode Problem-Based Learning adalah opsi yang dapat dipergunakan untuk menunjang kegiatan Student-Centered Learning karena penggunaan masalah dalam proses pembelajaran dapat memicu rasa keingintahuan mahasiswa sehingga akan mengarahkannya untuk dapat menyelesaikan permasalahan dengan memberikan definisi terhadap masalah serta menetapkan informasi yang telah dikumpulkan atau sedang dicari. Dengan jalan ini, mahasiswa akan berusaha mengaitkan informasi yang mereka miliki serta mampu menetapkan topik yang akan mereka pelajari lebih lanjut.

\section{Kata Kunci: Metode Problem-Based Learning (PBL) dan Student-Centered Learning $(S C L)$}

\section{PENDAHULUAN}

Pendidikan nasional memiliki tujuan untuk mencerdaskan kehidupan bangsa dan membuat masyarakat Indonesia berkembang seutuhnya menjadi manusia beriman dan berbudi pekerti luhur, menguasai pengetahuan dan keterampilan, sehat secara jasmani dan rohani, memiliki pribadi yang baik serta mandiri dan juga mempunyai rasa tanggungjawab terhadap masyarakat dan bangsa. Pendidikan tinggi adalah keberlanjutan dari jenjang pendidikan Menengah yang memiliki tujuan untuk mempersiapkan peserta didik menjadi warga Negara yang mempunyai kemampuan akademik serta profesional yang mampu untuk menerapkan, mengembangkan, bahkan bila perlu menciptakan pengetahuan-pengetahuan baru di segala bidang.

Pendidikan tinggi di Indonesia memiliki tujuan untuk menyebarluaskan dan mengembangkan pengetahuan serta memaksimalkan implementasinya untuk menaikkan taraf hidup masyarakat dalam level nasional serta membuat kebudayaan nasional semakin kaya. Esensi proses pembelajaran ialah adanya perubahan dalam diri peserta didik yang meliputi beberapa aspek, seperti misalnya afektif, kognitif, dan psikomotor, di samping kebiasaan dalam berinteraksi dengan lingkungan sekitar. Hakikat belajar sejatinya merupakan pembangunan pengetahuan melalui experience transformation, sehingga proses pembelajaran bisa dikatakan sukses apabila dalam diri peserta didik-beberapa ranah yang disebutkan di atasdapat secara maksimal terbentuk lebih baik dari sebelumnya. Kegiatan pembelajaran teraktualisasi dikarenakan terjadinya interaksi antara peserta didik dengan lingkungan belajar yang kondusif secara mandiri atau dirancang dengan sengaja. Individu yang belajar dengan mandiri secara luas dikenal dengan istilah otodidak, sebaliknya individu yang melakukan pembelajaran dikarenakan lingkungan belajar yang sengaja dibuat dikenal dengan istilah pendidikan formal. Pelaksanaan aktivitas pembelajaran terjadi sebagian besar memang 
dirancang sebelumnya. Aktivitas ini adalah tahapan penataan kondisi dan juga lingkungan belajar untuk dapat menciptakan proses pembelajaran yang maksimal. Sistem dan tahapan seperti di atas diistilahkan sebagai proses pembelajaran aktif. Baiknya suatu aktivitas pembelajaran dapat dilihat dari peserta didik yang dimungkinkan untuk terlibat secara aktif dalam keseluruhan proses secara fisik dan mental. Proses pembelajaran yang memang seharusnya terjadi di kelas adalah pembelajaran yang mengandung variasi klasikal, kelompok, maupun perorangan. Dalam hal ini pendidik (dosen) mempunyai fungsi sebagai fasilitator dalam proses pembelajaran dan juga menjadi manager untuk mengatur kelas agar tetap dalam jalur pembelajaran yang efektif. Di samping itu, peserta didik juga diharapkan melibatkan diri dalam aktivitas perasaan atau pikiran, berkomunikasi sebanyak mungkin, sehingga tercipta situasi kelas yang demokratis dan fleksibel, di samping menantang, namun mengacu pada tujuan pembelajaran yang ingin dicapai.

Menganalisa lebih dalam mengenai kata 'proses', mengarahkan kita untuk menuju pada kerangka berpikir tentang input-proses-output. Dalam kegiatan belajar mengajar, mahasiswa merupakan input dan alumni adalah outputnya. Sejatinya, cara pandang seperti ini akan mengarahkan kita sebagai pendidik untuk memposisikan mahasiswa sebagai objek yang terkadang harus menjadi pihak yang disalahkanjika output yang diwujudnyatakan berupa alumni-berkualitas tidak mampu dihasilkan selama proses pembelajaran berlangsung. Dengan demikian, hal yang sebaiknya mendapat perhatian adalah pendidik menempatkan mahasiswa sebagai subjek dari pembelajaran.

Pembelajaran sebagai sebuah proses dapat dipahami melalui identifikasi siapa yang melakukan apa, dimana, dan dalam keadaan bagaimana. Aktivitas pembelajaran sebenarnya telah berlangsung ketikaindividu ada pada usia sangat dini. Proses belajar ini mesti dijalani oleh individu yang berkeinginan belajar, tidak dapat diwakilkan oleh orang lain, akan tetapi dapat didampingi atau ditemani oleh orang lain. Sesuai dengan pernyataan di atas, ini menyebabkan semua pihak yang melibatkan diri secara aktif dalam proses pembelajaran akan semakin menjadi terpelajar.

Attard (2010: 86) dan tim dari Education International (EI) dan European Students' Union memiliki pendapat yang menyatakan bahwa kegiatan pembelajaran yang paling baik adalah dengan pelibatan seluruh mahasiswa agar mempelajari materi yang mereka dapatkan secara aktif. Di waktu yang sama pendidik memiliki peran sentral dalam memfasilitasi peserta didiknya agar tetap belajar dengan serius. Contoh dari memfasilitasi seperti yang dinyatakan di atas adalah penugasan peserta didik untuk melakukan penelitian kecil sembari memberikan peluang kepada mereka untuk menyajikan hasil kajian yang mereka telah lakukan dan kemudian melakukan diskusi dalam peer group serta yang terakhir adalah membuat kesimpulan dari hasil diskusi yang telah mereka lakukan. Angele Attard membentuk sebuah perbandingan capaian hasil belajar seperti di atas dan kemudian ia menuangkannya ke dalam tabel seperti di bawah ini.

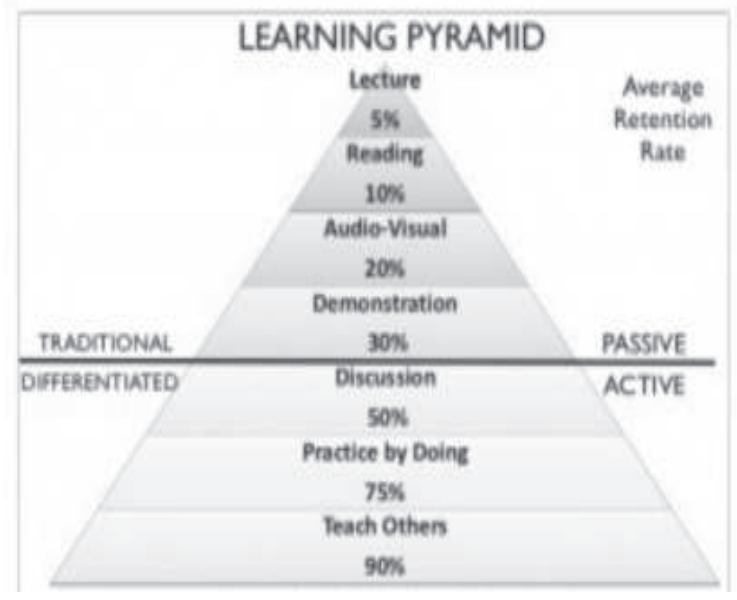

Memperhatikan diagram di atas, sangatlah terlihat jelas bahwa pembelajaran dengan model passive learning yang dilakukan dengan cara 
ceramah, audio visual, demonstrasi, ataupun membaca, hanya bisa mendapatkan pencapaian belajar 30\% sebagai angka yang paling tinggi. Bahkan apabila yang diandalkan adalah hanya audio visual, kuliah, ataupun membaca mandiri, pencapaian materi pelajaran yang dapat diingat serta melekat dalam ingatan peserta didik masin-masing hanya mencapai angka $20 \%$, $10 \%$, dan bahkan 5\% saja. Persentase pencapaian hasil seperti yang dijabarkan di atas terkesan sangat berbeda dengan pembelajaran dengan menggunakan model diskusi dan belajar aktif, praktik, dan lain sebagainya. Pencapaian terendah yang dihasilkan dari metode diskusi adalah 50\% sedangkan mengajar yang lain serta praktik menorehkan persentase belajar yang lebih tinggi yaitu $75 \%$ dan $90 \%$. Belajar mengajar dengan metode yang terakhir adalah penjelasan mengenai informasi pengetahuan yang telah dipelajari sebelumnya melalui peer group-nya dengan cara berdiskusi dan saling bertanya, melakukan dialog, bahkan berdebat. Sehingga proses belajar mengajar berbasis mahasiswa atau Student-Centered Learning pada saat sekarang ini sangatlah direkomendasikan dengan tujuan agar pesderta didik dalam hal ini mahasiswa dapat memperoleh hasil belajar yang optimal.

Kemudian apa yang diistilahkan sebenarnya dengan Student-Centered Learning? Melihat dari pengertiannya, Student-Centered Learning adalah sebuah kegiatan belajar mengeajar yang berpusat pada peserta didik atau mahasiswa. Dalam arti lain metode ini menuntut peserta didik menjadi pelaku aktif dalam proses belajar mengajar. Hal ini tentunya sangat kontras dengan TeacherCentered Learning di mana kegiatan belajar mengajar lebih banyak didominasi atau berpusat pada pendidik. Lebih rinci, definisi mengenai Student-Centered Learning disampaikan oleh Rodolfo P. Ang (2001:86), dari Loyola School Ateneo de Manila University. Menurut pendapatnya, StudentCentered Learning merupakan metode pembelajaran yang dapat memfasilitasi ntiap peserta didik agar melibatkan diri secara aktif dalam kegiatan belajar mengajar. Keaktifan ini diimplementasikan dengan membaca bukubuku teks, membaca digital book atau electronic book dalam komputer atau laptop, mencari bahan dari setiap sumber online dan kemudian terakhir mendiskusikan setiap informasi yang mereka telah dapatkan, selain pembelajaran yang dilakukan dari segala jenis sumber tadi. Kegiatan ini akan membuat mahasiswa melakukan pembelajaran dengan hati yang riang dan menikmati tiap tahapannya, terlepas dari pembelajaran tersebut dilakukan di kelas ataupun di luar kelas.

Ada banyak sekali manfaat dari kegiatan belajar mengajar dengan metode StudentCentered Learning bagi peserta didik maupun pendidik seperti yang dikemukakan oleh Angele Attard dari Education International yaitu:

Pertama, cara ini akan membuat para peserta didik menjadi bagian integral dari sebuah komunitas akademik. Sejatinya peserta didik kini dapat disebut sebagai civitas akademika, namun hal ini sering tidak maksimal dapat terwujud dikarenakan pendidik tidak memperlakukan mereka sebagai masyarakat akademik, akan tetapi sebagai objek pada saat ceramah ataupun memberikan perkuliahan.

Kedua, memperbaiki serta meningkatkan motivasi belajar tiap peserta didik. Hal ini dimungkinkan untuk terjadi karena sistem dari Student-Centered Learning akan memposisikan peserta didik sebagai masyarakat akademik yang mesti memahami teori kemudian dapat mengaplikasikannya serta mengerjakan evaluasi beserta kajian-kajian atas teori tersebut. Dalam hal ini setiap peserta didik juga dituntut untuk dapat menyajikan informasi atau hasil kajiannya pada peer group ataupun pendidik yang telah membinanya sehingga mereka akan dengan otomatis menjadi termotivasi untuk memperbanyak kegiatan pembelajaran di luar kelas. Dan hal ini akan mendorong terbentuknya masyarakat pelajar. 
Ketiga, peserta didik menjadi lebih mandiri dan memiliki tanggungjawab untuk terus meningkatkan kegiatan pembelajaran. Proses belajar mengajar berbasis Student-Centered Learning membuat peserta didik selalu berada dalam keterikatan untuk mempelajari suatu hal. Hal ini dikarenakan adanya tuntutan untuk mereka agar selalu dapat menyajikan dan mempresentasikan apa yang telah didapat dalam penelitian kepada peer group dan pendidik sehingga peserta didik secara otomatis harus bertanggungjawab secara mandiri karena adanya tuntutan untuk selalu melengkapi informasi keilmuan yang tentunya mereka perlukan untuk disajikan di depan kelas dalam setiap pertemuannya

Manfaat yang terakhir adalah arus masuk pendidikan tinggi yang semakin tinggi serta keperluan pasar yang semakin banyak dan beragam sehingga kebutuhan pembelajaran para peserta didik juga menjadi makin diversifikatif disesuaikan dengan arah profesi yang akan dituju peserta didik setelah selesai mengenyam pembelajaran di perguruan tinggi. Student-Centered Learning memberikan peluang kepada peserta didik untuk belajar keilmuan yang ditekuninya dengan cara mandiri serta tidak adanya keterikatan dengan bahan ajar yang menjadi sentral kajian kelompok atau peserta didik lain dari jurusan atau program studi yang berlainan atau bahkan mungkin dari jurusan atau program studi yang sama.

Student-Centered Learning mempunyai peluang untuk mendorong peserta didik menjadi lebih aktif dalam belajar didasarkan atas irama belajar masing-masing individu. Hal ini tentu disesuaikan dengan usia individu. Kemudian irama belajar itu harus dipandu untuk dapat tetap berlangsung dinamis dan memiliki tingkat kompetensi yang tinggi

Metode Problem-Based Learning adalah pemecahan masalah yang merupakan salah satu pembelajaran konstruktivisme yang merupakan sebuah alternatif belajar yang bisa diimplementasikan dalam usaha untuk menanggulangi terjadinya miskonsepsi selain daripada strategi belajar mengajar yang lain, misalnya melalui analogi hubungan, wawancara dialogis, diskusi kelompok, simulasi komputer, peta konsep, pengalaman lapangan atau percobaan serta pertanyaan terus menerus (Suparno, 2005: 46). Pada bagian ini, pendidik bisa memberikan permasalahan berdasarkan topik atau tema yang dipelajari saat itu. Kemudian peserta didik diminta agar dapat memecahkan permasalahan tersebut, baik secara individu maupun kelompok. Dengan pemecahan masalah, peserta didik dilatih dalam pengorganisasian kemampuan dan pengetahuannya. Hal ini menjadi penting agar peserta didik mengungkapkan alasannya melakukan pengerjaan dengan caranya sendiri termasuk bagaimana ia memecahkan masalah.

Dengan melakukan pengamatan terhadap peserta didik dalam pemecahan masalah, tenaga pendidik akan mudah menentukan apakah peserta didik mengalami miskonsepsi atau tidak. Ketika pendidik mengetahui adanya miskonsepsi pada peserta didik, maka ia diharapkan dapat dengan segera merumuskan dan melakukan langkah reduksi miskonsepsi. Sejalan dengan prinsip konstruktivisme, pembelajaran adalah sebuah proses konstruksi pemahaman terhadap dunia. Dalam hal ini, peserta didik mengkonstruksikan pengetahuan dalam pikiran mereka masing-masing (Demitra 2003: 34).

\section{PEMBAHASAN}

\subsection{Pendidikan untuk Pebelajar Dewasa}

Pendidikan untuk pebelajar dewasa berbeda dengan pendidikan untuk pebelajar usia remaja atau anak-anak. Pendidikan untuk pebelajar dewasa lebih dititikberatkan pada keinginan kuat untuk belajar secara mandiri ataupun peningkatan kegiatan bertanya mengenai hal-hal ilmiah sesuai dengan bidang pendidikannya. Hal senada dijelaskan Pannen (dalam Supriantono, 2008: 76) bahwa 
pendidikan dewasa merupakan proses penumbuhkembangan hasrat untuk bertanya serta belajar secara kontinyu sepanjang hayat. Untuk pembelajar dewasa, belajar erat kaitanya dengan pengarahan diri sendiri untuk bertanya harta mendapatkan jawaban yang diinginkan..

Menurut UNESCO (dalam Supriantono, 2008), pendidikan orang dewasa adalah keseluruhan proses pendidikan dengan hal-hal yang diorganisasikan sebagai berikut, yaitu isi, tingkatan, dan metodenya, baik secara formal ataupun tidak terhadap emua program yang ada di jenjang pendidikan seperti sekolah dan universitas serta tempat pelatihan kerja yang membuat peserta didik diakui dewasa oleh masyarakat sehingga dapat mengembangkan kemampuannya, memperluas pengetahuannya, terus meningkatkan kualifikasi teknis, dan profesionalnya, sehingga dapat menyebabkan adanya perubahan sikap dan perilakunya dalam perspektif perkembangan pribadi secara holistik serta partisipasi dalam pengembangan ekonomi, sosial, dan budaya yang bersifat seimbang serta bebas. Dengan demikian didefinisikan bahwa pendidikan terhadap peserta didik dewasa mesti terorganisir dengan baik serta memiliki orientasi pada pengembangan dan perubahan afektif, kognitif, dan psikomotor, serta partisipasi aktif dalam pengembangan ekonomi, sosial, dan budaya.

Peserta didik dewasa dapat dikategorikan dalam tiga aspek, diantaranya: aspek biologis, yaitu mereka yang disebut dewasa ketika telah mampu melakukan reproduksi. Kedua, psikologis, dalam hal ini peserta didik disebut dewasa ketika mempunyai tanggung jawab terhadap keputusan yang diambil serta dalam kehidupan. Ketiga, sosiologis, dalam hal ini peserta didik disebut dewasa ketika telah dapat mengerjakan aktivitas-aktivitas sosial yang dibebankan kepadanya.

\subsubsection{Kondisi dan Prinsip Belajar Orang Dewasa}

Terdapat beberapa situasi belajar, pembelajaran, serta prinsip pembelajaran dari peserta didik dewasa. Diantaranya, ketika peserta didik memiliki kebutuhan belajar, maka pada prinsipnya pengajar atau pendidik mengemukakan beberapa kemungkinan baru dalam memenuhi keinginan peserta didik serta memberikan bantuan setiap saat.

Lindeman (tahun: hal) menyatakan bahwa terdapat 5 prinsip-prinsip pembelajaran dari teori belajar orang dewasa. Pertama, peserta didik dewasa akan memiliki motivasi untuk melakukan pembelajaran yang dapat mengisi kebutuhan dan memenuhi minatnya, sehingga titik awal dari pembelajaran peserta didik dewasa adalah menemukan kebutuhan serta minat terhadap aktivitas belajar. Kedua, peserta didik dewasa memiliki orientasi pembelajaran yang berpusat pada kehidupan sehingga pembelajaran peserta didik dewasa mesti memiliki kaitan erat dengan kehidupan, tidak hanya kaitan dengan pelajaran. Ketiga, pengalaman merupakan sumber pembelajaran yang terbaik bagi pembelajar dewasa. Oleh sebab itu, strategi yang digunakan adalah lebih banyak mengenai pengalaman dan analisis pengalaman. Keempat, selanjutnya peserta didik dewasa memiliki keinginan yang kuat dalam mengarahkan diri mereka sendiri sehingga pengalaman merupakan guru dalam proses belajar mengajar dengan pengembangan pengetahuan. Kelima adalah perbedaan antara individu dalam komunitas peserta didik dewasa semakin mengalami pertambahan, sejalan dengan pertambahan usia yang terjadi, sehingga gaya belajar, tempat, waktu, serta kecepatan belajar mesti ditolerir.

\subsubsection{Asumsi-Asumsi Pokok Teori Belajar Orang Dewasa}

Knowles (1970: 125) menyatakan bahwa ada empat pokok asumsi, sebagai berikut yaitu: 
Pertama, konsep diri, yang memiliki asumsi bahwa kesungguhan dan kematangan diri peserta didik berawal dari ketergantungan total pada pengembangan dirinya sendiri, karena hal itu dapat mengarahkan diri peserta didik sendiri secara mandiri. Dengan adanya kemandirian ini, peserta didik dewasa memerlukan adanya pengakuan atau penghargaan dari orang lain sebagai seorang individu yang mempunyai prinsip dan dapat menentukan dirinya sendiri serta mengarahkan dirinya sendiri.

Kedua, peranan pengalaman, yang memiliki asumsi bahwa berdasarkan perjalanan waktu, peserta didik tumbuh dan berkembang ke arah yang semakin matang. Dalam perjalanannya, peserta didik mendapatkan berbagai macam pengalaman kehidupan sehingga secara langsung maupun tidak langsung dapat membuat peserta didik menjadi sumber belajar yang sedemikian kaya, dan kemudian pada saat yang sama, peserta didik tersebut memberikan dasar yang luas untuk melakukan proses pembelajaran, serta mendapatkan pengalaman yang baru.

Ketiga, kesiapan belajar, yang memiliki asumsi bahwa tiap peserta didik menjadi semakin matang disesuaikan dengan perjalanan waktu masing-masing. Sehingga kesiapan dalam melakukan proses pembelajaran tidak semata ditentukan oleh keperluan ataupun tuntutan akademik maupun biologisnya, tetapi lebih banyak ditentukan oleh tuntutan perkembangan serta perubahan dalam peran sosial individu tersebut. Misalnya seorang anak melakukan proses pembelajaran dikarenakan adanya tuntutan akademik serta biologisnya, akan tetapi pada orang dewasa proses pembelajaran dilakukan karena peranannya sebagai pekerja, orang tua, ataupun pemimpin sebuah organisasi. Hal-hal semacam ini memiliki dampak terhadap materi pembelajaran dalam suatu aktivitas belajar atau pelatihan tertentu. Dalam hal ini materi pembelajaran tentunya mesti ada penyesuaian dengan kebutuhan yang sesuai dengan peran sosial peserta didik dewasa.
Keempat, orientasi belajar, yang memiliki asumsi yaitu orientasi belajar pada anak seakan-akan telah ditentukan dan disituasikan agar mempunyai orientasi yang terpusat pada materi pembelajaran. Sedangkan pada orang dewasa, orientasi belajarnya memiliki kecenderungan terpusat pada pemecahan sebuah permasalahan yang sedang dihadapi. Hal ini disebabkan karena proses pembelajaran bagi individu dewasa seakan-akan adalah merupakan keperluan untuk menghadapi berbagai macam permasalahan yang muncul dalam kehidupan sehari-hari terutama yang memiliki kaitan erat dengan fungsi serta peran sosial dari peserta didik dewasa tersebut.

\subsection{Proses dan Pendekatan Pembelajaran di Perguruan Tinggi}

Kamus Webster's New World dictionary (1962: 198), menyatakan bahwa pendidikan merupakan tahapan pengembangan serta latihan yang mencakup komponen pengetahuan, kepribadian, serta keterampilan, yang utamanya dilakukan dalam bentuk aktivitasaktivitas pendidikan yang mencakup proses dalam mencetak lulusan berkualitas serta transformasi pengetahuan yang dikerjakan oleh peserta didik atau organisasi belajar (dalam Fattah 2004: 14).

Untuk mempersiapkan sumber daya manusia serta warga negara yang baik, Siswoyo, dkk. (2007: 83) menyatakan Pendidikan Nasional bertujuan untuk mengembangkan potensi individu sehingga dapat menjadi manusia yang memiliki iman dan taqwa kepada Tuhan Yang Maha Esa, sehat, berilmu, memiliki akhlak mulia, kreatif, mandiri, serta dapat menjadi warga negara yang demokratis dan bertanggung jawab (UndangUndang No. 20 tahun 2003 pasal 3).

Tahapan dalam pendidikan memerlukan sumber daya manusia yang dapat membimbing para generasi penerus bangsa. Sumber daya manusia yang dimaksudkan disini adalah pendidik. Tahapan dalam menghasilkan output 
yang berkualitas dilakukan di perguruan tinggi. Pendidikan tinggi adalah tumpuan terakhir dari keseluruhan jenjang pendidikan serta difungsikan sebagai wahana pembentukan output atau sarjana yang mempunyai budi pekerti luhur, nilai-nilai kearifan, serta dapat memajukan kehidupan (Harsono 2008: 22).

\subsection{Student-Centered Learning}

Hadi (2007: 56) menjelaskan bahwa pembelajaran Student-Centered Learning memiliki arti bahwa peserta didik mesti didorong agar mempunyai motivasi dalam diri sendiri. Dengan demikian dapat berusaha secara keras untuk memiliki skill ataupun kompetensi yang diharapkan. Hal ini dapat dikerjakan dengan metode Student-Centered Learning sehingga dalam hal ini peserta didik diberikan ruang gerak untuk mengungkapkan pendapat-pendapatnya secara jelas. Kemudian mampu menyelesaikan setiap permasalahan yang ditemui. Harapannya, dengan diterapkannya Student-Centered Learning, peserta didik mampu menempuh program belajar dengan tidak adanya kendala, serta tepat waktu berdasarkan target, atau malah dapat menyelesaikan studi lebih cepat dari yang ditargetkan. Selanjutnya ketika peserta didik sudah ada di dunia kerja, mereka akan mampu berkompetisi dengan yang lain.

Menurut Harsono (dalam Sudjana 2005: 37), Student-Centered Learning adalah sebuah pendekatan dalam kegiatan belajar mengajar yang bisa digunakan untuk memfasilitasi peserta didik untuk dapat melibatkan diri secara aktif dalam proses experiential learning. Pada saat ini, StudentCentered Learning diharapkan mampu menjadi pendekatan kegiatan belajar mengajar yang sebaiknya digunakan oleh setiap perguruan tinggi karena memiliki banyak keunggulan, diantaranya yang pertama adalah peserta didik bisa merasakan bahwa proses belajar mengajar menjadi miliknya sendiri karena mereka diberikan ruang gerak untuk berpartisipasi secara aktif dalam proses. Yang kedua peserta didik mempunyai motivasi yang tinggi dalam mengikuti setiap kegiatan pembelajaran, sehingga suasana demokratis akan tumbuh dengan sendirinya dalam pembelajaran, dan hal ini akan memunculkan dialog serta diskusi sehingga peserta didik dapat saling belajar serta membelajarkan diri. Dan yang terakhir yaitu hal ini mampu meningkatkan wawasan atau pengetahuan bagi pendidik karena apa yang disampaikan oleh peserta didik mungkin saja adalah merupakan informasi baru atau belum pernah diketahui sebelumnya. Keunggulan-keunggulan seperti yang sudah dijelaskan di atas mampu mendukung upaya Student-Centered Learning untuk menciptakan kegiatan belajar mengajar yang lebih efektif serta efisien.

Penerapan Student-Centered Learning di perguruan tinggi bertujuan agar peserta didik belajar secara aktif dan menekankan pembelajaran pada sumber belajar, sehingga dalam hal ini, proses belajar mengajar dapat mengembangkan kreatifitas berpikir peserta didik. Selain itu, Student-Centered Learning dapat mengkontruksi pengetahuan sebagai upaya untuk memperbaiki serta meningkatkan pemahaman yang baik terhadap materi pembelajaran (Dikti, 2004: 78).

\subsection{Problem-Based Learning}

\subsubsection{Pengertian Problem-Based Learning}

Pembelajaran berbasis masalah atau Problem-Based Learning merupakan sebuah model pembelajaran yang berpusat pada siswa, memposisikan siswa dengan berbagai macam permasalahan yang ditemuinya dalam kehidupannya sehari-hari. Dengan menggunakan metode belajar mengajar seperti ini, siswa sedari awal diajarkan untuk menghadapi dan menyelesaikan permasalahan seperti yang mereka akan temui dalam kehidupannya ke depan.

Problem-Based Learning adalah cara untuk menyajikan permasalahan sebagai titik 
tolak pendiskusian permasalahan, untuk kemudian dilakukan analisis dan disintesis dalam kegiatan pemecahan masalah oleh peserta didik. Permasalahan dapat diberikan oleh pendidik, kemudian pendidik bersama peserta didik bersama-sama melakukan analisis serta kemudian berusaha untuk menyelesaikan peermasalahan tersebut. Dengan demikian, metode pembelajaran berbasis masalah atau Problem-Based Learning merupakan sebuah metode pembelajaran yang berfokus pada akar permasalahan dan kemudian memecahkan masalah tersebut (Abuddin, 2011: 243).

Kemudian Stephen, dkk. (dalam Ngalimun, 2013:89) menyebutkan bahwa Problem-Based Learning adalah sebuah metode pembelajaran yang melibatkan partisipasi aktif peserta didik untuk menyelesaikan sebuah permasalahan dengan melalui tahapan-tahapan analisis dengan metode ilmiah, sehingga pada akhirnya peserta didik dapat mempelajari pengetahuan yang memiliki hubungan erat dengan permasalahan, serta sekaligus mempunyai keterampilan dalam pemecahannya. Sedangkan Dirjen Dikti (dalam Cholisin, 2006: 89) menyatakan pengertian Problem-Based Learning merupakan sebuah metode belajar mengajar yang menggunakan permasalahan kontekstual sebagai suatu situasi atau iklim bagi peserta didik untuk belajar, dengan cara memiliki pikiran kritis dan memecahkan permasalahan serta mendapatkan pengetahuan dan konsep penting dari sebuah pembelajaran.

Berdasarkan apa yang telah dijelaskan di atas, maka dapat ditarik kesimpulan bahwa Problem-Based Learning adalah sebuah metode pembelajaran yang terfokus pada pelacakan akar permasalahan yang sering dijumpai di lingkungan sehari-hari sebagai konteks pembelajaran dengan pelibatan peserta didik dalam rangka memecahkan permasalahan melalui prosedur ilmiah. Dengan demikian, peserta didik diajarkan bagaimana berpikir kritis dan belajar melalui pengalaman dalam memecahkan permasalahan sehingga mendapatkan pengetahuan dan juga konsep penting dari materi-materi pembelajaran.

\subsubsection{Model Pembelajaran Berbasis Masalah (Problem-Based Learning)}

Dalam implementasi metode belajar mengajar yang berfokus pada penyelesaian masalah atau pembelajaran berbasis masalah, pendidik memberikan kesempatan yang sebesar-besarnya pada peserta didik untuk menetapkan tema permasalahan yang memiliki kaitan dengan materi pembelajaran, meskipun dalam hal ini, pendidik mempersiapkan materi yang harus didiskusikan dalam sebuah pembelajaran. Kegiatan belajar mengajar diarahkan agar peserta didik dapat menyelesaikan permasalahan secara logis serta sistematis.

Meihat lebih detail pada aspek psikologi, pembelajaran berbasis masalah (ProblemBased Learning) berlandaskan pada psikologi kognitif yang bertitik tolak dari sebuah pandangan bahwa pembelajaran merupakan tahapan perubahan perilaku berkat adanya pengalaman (Sanjaya, 2010: 213). Kegiatan belajar mengajar bukanlah semata-mata kegiatan untuk menghafalkan banyak teks atau fakta empiris, tapi lebih merupakan sebuah tahapan interaksi secara sadar yang terjadi antara peserta didik dan lingkungannya. Dengan dilakukannya tahapan ini, peserta didik akan berkembang secara utuh sedikit demi sedikit. Ini berarti bahwa perkembangan mereka tidak hanya ada dan terlihat dari aspek kognitif saja, melainkan juga aspek afektif dan psikomotor.

Ngalimun (2013:90), menyebutkan bahwa dalam metode Problem-Based Learning, titik konsentrasi ada pada permasalahan yang disajikan. Sehingga dalam hal ini peserta didik melakukan pembelajaran terhadap konsepkonsep yang memiliki kaitan dengan permasalahan. Akan tetapi juga mempelajari metode ilmiah yang dapat digunakan dalam pemecahan masalah tersebut. Oleh karenanya 
bukan saja mesti paham dengan baik konsep yang relevan dengan permasalahan yang menjadi pusat perhatian, tetapi dapat juga memperoleh pengalaman mengenai pembelajaran yang ada kaitannya dengan keterampilan dalam menerapkan pendekatanpendekatan ilmiah guna menyelesaikan permasalahan serta membiasakan diri untuk memiliki pola berpikir kritis.

Selain itu Sanjaya (2010: 214-215), menyebutkan ada tiga karakteristik utama dari Problem-Based Learning. Pertama, ProblemBased Learning merupakan rangkaian kegiatan belajar mengajar, artinya adalah bahwa dalam penerapan Problem-Based Learning ada kegiatan yang mesti dikerjakan oleh peserta didik. Problem-Based Learning menuntut siswa tidak hanya sekedar mendengarkan, mencatat, dan menghafalkan materi-materi pembelajaran tetapi lebih jauh melalui ProblemBased Learning, peserta didik diharapkan dapat berpikir aktif dan berkomunikasi, serta mencari, dan mengolah data, dan pada akhirnya membuat kesimpulan-kesimpulan. Kedua, kegiatan belajar mengajar ini memposisikan permasalahan sebagai titik tolak dalam proses belajar mengajar. Ketiga, pemecahan masalah dikerjakan dengan segmentasi dari pendekatan berpikir ilmiah. Dalam proses berpikir dengan penggunaan metode ilmiah, proses berpikir deduktif dan induktif dikerjakan dengan sistematis serta empiris.

Dari penjelasan yang sudah disampaikan di atas, maka dapat disimpulkan bahwa implementasi metode Problem-Based Learning sangat diharapkan agar dapat memperbaiki serta meningkatkan hasil belajar peserta didik, sehingga nantinya peserta didik diharapkan mampu mengimplementasikan kompetensinya tersebut dalam kehidupannya sehari-hari.

\section{SIMPULAN}

Problem-Based Learning adalah metode belajar mengajar yang cocok untuk diterapkan pada kegiatan belajar mengajar di perguruan tinggi. Sebabnya adalah metode ProblemBased Learning sangatlah berbeda dengan kebanyakan pendekatan yang lain termasuk pendekatan konvensional. Problem-Based Learning adalah metode belajar mengajar yang didasari oleh sebuah permasalahan. Metode ini menuntut pelibatan aktivitas berpikir dalam kegiatan belajar mengajar agar dapat memecahkan masalah dengan cara yang tepat. Problem-Based Learning memiliki korelasi positif dengan fungsi kognitif yang berisi berbagai jenis kegiatan berpikir dan hal ini tertuang dalam tahapan-tahapan kegiatan pembelajarannya antara lain prior knowledge, reorganisasi, pengetahuan baru, kemudian proses analisis, serta sintesis, strukturisasi, pengembangan ide ide, dan yang terakhir adalah pemecahan permasalahan.

Beberapa karakteristik dari ProblemBased Learning adalah misalnya permasalahan yang akan diselesaikan diinformasikan lebih dahulu sebelum peserta didik mempunyai pengetahuan baru, yang didasarkan untuk pemecahan permasalahan yang bersifat integratif, serta adanya penilaian terhadap kegiatan dalam memecahkan permasalahan.

Problem-Based Learning dalam hal ini sangat tepat diterapkan untuk StudentCentered Learning. Problem-Based Learning dalam level pendidikan tinggi memiliki kontribusi yang besar untuk membentuk kompetensi peserta didik dalam menerapkan beberapa teori dan pendekatan teoritis, terhadap beberapa situasi dalam sebuah komunitas yang fokus pada permasalahan hidup individu, sebagai akibat dari interaksi mereka dengan lingkungan dari proses pembelajaran. Dengan menggunakan Problem-Based Learning, diharapkan peserta didik akan memiliki sensitifitas tinggi terhadap permasalahan di sekitarnya, sehingga pada akhirnya mereka dapat menstimulasikan kemampuan mereka untuk mencari solusi dalam pemecahan masalah dengan menggunakan banyak sudut pandang. 


\section{DAFTAR PUSTAKA}

Abuddin, Nata. 2011. Manajemen Pendidikan, Mengatasi Kelemahan Pendidikan di Indonesia. Jakarta: Kencana Prenada Media Group.

Attard, Angela, et all. 2010. Student Centred Learning, Toolkit for students Staffs, and Higher Education Institution. Education International and the European Student Union, Brussel, Belgia.

Cholisin. 2006. Pengembangan Karakter Dalam Materi Pembelajaran. Makalah disampaikan pada kegiatan MGMP PKn SMP Kota Yogyakarta.

Demitra. 2003. Pembelajaran Pemecahan Masalah dengan Pendekatan Problem Based Learning. Makalah disampaikan dalam Seminar Nasional Teknologi Pembelajaran di Hotel Inna Garuda.

Departemen Pendidikan Nasional. 2003. Undang-Undang No. 20 Tahun 2003, Tentang Sistem Pendidikan Nasional, Jakarta: Depdiknas.

Departemen Pendidikan Nasional, Ditjen Dikti Depdiknas. 2004. Tanya Jawab Seputar Unit dan Proses Pembelajaran di Perguruan Tinggi.

Fattah, Nanang. 2004. Konsep Manajemen Berbasis Sekolah (MBS) dan Dewan Sekolah. Bandung: Pustaka Bani Quraisy.

Hadi, Rahmini. 2007. Dari Teacher-Centered Learning ke Student-Centered Learning:
Perubahan Metode Pembelajaran di Perguruan Tinggi.

Jurnal Pemikiran Alternatif Pendidikan, Vol. 12, No.3.

Harsono, 2008. Pengelolaan Perguruan Tinggi.Yogyakarta: Pustaka Pelajar.

Knowles, Malcolm S. 1970. The Modern Practice of Adult Education. Andragogy versus Pedagogy. New York: Association Press.

Ngalimun. 2013. Strategi dan Model Pembelajaran. Yogyakarta: Aswaja Pressindo.

Redolfo, P. Ang. 2001. Elements of Student Centred Learning. Loyola Schools Loyola Antenoe de Manila Uniersity, Office of Research and Publication.

Sanjaya, Wina. 2010 Strategi Pembelajaran Berorientasi Standar Proses Pendidikan. Jakarta: Kencana Prenada Group.

Siswoyo, Dwi, dkk. 2007. Ilmu Pendidikan. Yogyakarta: UNY Press.

Sudjana, Nana. 2005. Penilaian Hasil Proses Belajar Mengajar. Bandung: PT Remaja Rosdikarya.

Suprianto, Dodit. 2008. Dasar Pemrograman PHP. Bandung: Oase Media.

Tiffin, John, dan Rajasingham, L. 1995. In Search of the Virtual Class: Education in An Informational Society. London: Routledge. 